\title{
Life-threatening cardiovascular adverse events related to pectus excavatum surgery
}

\author{
Julien De Wolf', Valentin Loobuyck ${ }^{2}$, Emmanuel Brian $^{3}$, Alain Wurtz ${ }^{3 *}$ and Lotfi Benhamed \\ ${ }^{1}$ Thoracic Department, Foch Hospital, Suresnes, France \\ ${ }^{2}$ Division of Cardiac and Thoracic Surgery, CHU Lille, Lille, France \\ ${ }^{3}$ Department of Thoracic, Curie-Montsouris Thorax Institute, Institut Mutualiste Montsouris, Paris, France \\ ${ }^{4}$ Department of Thoracic Surgery, CHR Valenciennes, Valenciennes, France
}

\begin{abstract}
Background: The occurrence of life-threatening cardiovascular adverse events related to pectus repair is underestimated.

Methods: Literature review of severe adverse events affecting the heart, pericardium and large vessels of open or minimally invasive repair.

Results: In patients undergoing Willital-Hegemann repair, we identified one death caused by intraoperative cardiac arrest. In patients undergoing Ravitch-type repair, we identified 11 non-lethal life-threatening cardiovascular adverse events: two per/postoperative cardiac injuries and six delayed intracardiac bar migrations (overall, six successful cardiac procedures under CPB were performed); and three intrapericardial migrations of broken sternal wire and consecutive tamponade treated by wire removal and pericardial drainage. Finally, we identified one aortic injury caused by a broken sternal wire 28 years after sternal turnover.

In patients undergoing minimally invasive repair we identified 27 cardiac injuries during procedure and three later Nuss-bar removal; one intracardiac migration of the Nuss-bar (overall, four patients died and 11 underwent cardiac procedures under CPB); three procedural vena cava injuries (one patient died); six obstructions of the inferior vena cava $(n=3)$ or right ventricular outflow tract $(n=3)$; three episodes of major bleeding from the ascending aorta (one patient died); two pericardiectomies and three late-onset cardiac tamponades. Eight patients sustained procedural or late-onset cardiac arrest (five patients died). Overall, we identified 56 life-threatening cardiovascular adverse events requiring 12 cardiac/aortic procedures under CPB. There were 11 deaths and two cases of severe hypoxic brain injury.
\end{abstract}

Conclusions: During pectus surgery, the cardiovascular morbidity/mortality related to minimally invasive repair appears more severe, in comparison to open repair.

\section{Introduction}

Pectus Excavatum (PEx) is the most common anterior chest wall deformity. Its pathogenesis is still controversial. However, overgrowth and/or distortion of costal cartilage play a key role in the pathophysiologic and clinical features of the disease [1]. The deformity usually worsens as the child grows [2]. While the indication for surgical management is mainly cosmetic it also aims at improving patients' quality of life [3] and exercise performance [4].

Management of complex chest wall deformities such as PEx has improved significantly over the past 50 years with high long-term success rates. However, following these procedures some life-threatening adverse events have been reported, mainly cardiovascular injuries. Due to the chest deformation, the anatomical ratios are modified, which facilitates the occurrence of heart or great vessel injury. Furthermore, other lesions can occur in the mid/long term due to steel wire or metal bar fracture and/or dislocation. Such cardiovascular adverse events are even less acceptable since this surgery is performed for cosmetic or psychological purpose in the majority of cases.

There are two types of PEx surgery: open and minimally invasive repair. The most usual open repairs are the Ravitch-type procedures based on the subperichondrial resection of abnormal cartilages combined with a transverse osteotomy across the anterior table of the upper sternum and the routine use of a metallic support bar to maintain the elevated sternum. This support bar is usually removed at six months [5-8]. One variant is the Willital-Hegeman technique, in which three metallic bars are used to stabilize the remodeled anterior chest wall [9]. Finally, the "sternal turnover", a $180^{\circ}$ reversal on its axis of the chondrosternal plastron after upper sternal section [10] is an operation currently abandoned.

The minimally invasive repair (or close repair) is commonly referred to MIRPE (Minimally Invasive Repair of Pectus Excavatum), or Nuss procedure [11]. Depending on the deformity, it consists of placing one or more preformed curved bars in the thoracic cavity under thoracoscopic control. Then a $180^{\circ}$ turning manoeuver of bar corrects the concavity of the anterior chest wall.

Based on literature data, the purpose of this study is to assess the occurrence of Life-Threatening Cardiovascular Adverse Event (LCAE) during PEx surgery, in both open and minimally invasive approaches.

${ }^{*}$ Correspondence to: Alain Wurtz, Department of Thoracic, Curie-Montsouris Thorax Institute, Institut Mutualiste Montsouris, 42 Boulevard Jourdan F75014, Paris, France, Tel: +33 1566162 80; E-mail: afwurtz@wanadoo.fr

Key words: pectus surgery, cardiovascular morbidity, life-threatening, cardiovascular adverse events

Received: January 02, 2019; Accepted: January 16, 2019; Published: January 21, 2019 


\section{Material and methods}

This review was designed according to the recommendations for systematic reviews of the literature and meta-analyses [12]. Bibliographic searches were conducted using the Pubmed, Medline, CINAHL, Cochrane and Embase bibliographic and bibliometric databases, including the following keywords: Pectus excavatum, close repair, Nuss, MIRPE, open repair, Ravitch, sternochondroplasty, complications, cardiovascular complications; including studies of prospective and retrospective series, case reports and case series, with cross-referencing of bibliographical references.

We selected the articles reporting or mentioning severe adverse events affecting the heart and/or large vessels, during PEx repair. Procedural pericardial contusion or laceration, or early postoperative effusion were not taken into account. On the other hand, we selected as LCAEs the delayed pericardial events such as constriction or late-onset tamponade. Cardiac rhythm disorders and damage to peripheral vessels (mainly the internal thoracic artery) were not taken into account.

A total of 531 medical articles were examined and 67 were selected, reporting cardiovascular adverse events severe enough to trigger lifethreatening or fatal prognosis. Articles published in English, French and Spanish were included. Additionally, we selected two articles from the non-medical literature, and took into account duplicate and triplicate studies reporting the same case of LCAE.

\section{Results}

\section{Pectus excavatum open repair}

After PEx open repair, we identified 13 LCAEs including one lethal case, as summarized in Table 1. This death was reported by Saxena and coworkers [9] in their series of 1262 patients treated by the WillitalHegemann procedure as a result of a peroperative cardiac arrest in a patient with an unspecified history of "cardiac abnormality".

\section{Procedural and postoperative lesions $(n=2)$}

The unique procedural cardiac injury was reported by Hernandez and coworkers [13]. In a child with a past history of neonatal cardiac surgery the injury occurred during an attempt of Ravitch-type repair in infancy. The definitive cure of PEx was performed at the age of 16 by means of Nuss-bar placement through sternotomy and Cardiopulmonary By-Pass (CPB) for safety reasons.

In the postoperative period, we identified an iatrogenic cardiac injury in a seven-year-old child who had undergone a PEx open repair using Kirchner wires to stabilize the remodeled anterior chest wall. Following blind replacement of a dislocated wire protruding beneath the skin on Day 5 , he sustained severe congestive heart failure. Emergent surgical exploration showed a pierced right atrium, a torn septal leaflet of the tricuspid valve and noncoronary aortic cusp, and a large traumatic ventricular septal defect. Lesions were repaired under CPB. However, the child showed residual tricuspid and aortic regurgitation as sequelae [14].

\section{Intracardiac migration of metal support bar $(n=6)$}

We identified two cases of early displacement (within six months) of a metal support bar in two young adults. One bar penetrated the right and left ventricle across the interventricular septum [15] and the other induced an aorta-to right ventricular fistula [16]. In both cases, the complication was caused by the use of a too short bar, thus facilitating unintended migration into the mediastinum. Four other

Table 1. Open repair. Characteristics and outcomes for 13 patients who sustained LCAE

\begin{tabular}{|c|c|c|c|c|}
\hline $\begin{array}{c}\text { Authors } \\
\text { (Procedure) }\end{array}$ & $\begin{array}{l}\text { Patient age (y) } \\
\text { Past history }\end{array}$ & Cardiac/Aortic injury (Delay) & $\begin{array}{l}\text { Approach for injury repair } \\
\text { (CPB) }\end{array}$ & Outcomes \\
\hline $\begin{array}{c}\text { Saxena [9] } \\
\text { (Wilital-Hegemann) }\end{array}$ & $(\mathrm{NM})$ & $\begin{array}{l}\text { Procedural unintended cardiac arrest in a patient with "unspecified } \\
\text { cardiac abnormality" (no cardiac injury) }\end{array}$ & None & Dead \\
\hline $\begin{array}{l}\text { Hernandez [13] } \\
\text { (Ravitch-type) }\end{array}$ & $\begin{array}{l}(\mathrm{NM}) \text {. Neonatal } \\
\text { cardiac surgery }\end{array}$ & $\begin{array}{l}\text { Procedural non-lethal cardiac injury during attempt of Ravitch-type } \\
\text { repair in infancy }\end{array}$ & NM & $\begin{array}{l}\text { Nuss-bar under } \mathrm{CPB} \\
\text { at } 16\end{array}$ \\
\hline $\begin{array}{c}\text { Pircova }[14] \\
\text { (Open repair + Kirchner wires) }\end{array}$ & (7) & $\begin{array}{l}\text { Right atrium, tricuspid valve, traumatic ventricular septal defect (blind } \\
\text { replacement of a Kirchner wire) } \\
\text { (Day 5). }\end{array}$ & Sternotomy (CPB) & $\begin{array}{l}\text { Tricuspid and aortic } \\
\text { regurgitation }\end{array}$ \\
\hline \multicolumn{5}{|c|}{ Intracardiac migration of metallic support bar } \\
\hline $\begin{array}{c}\text { Elami [17] } \\
\text { (Ravitch-type) }\end{array}$ & (12) & $\begin{array}{l}\text { Migration of broken metal bar into the right atrium } \\
\qquad(2 \text { years })\end{array}$ & $\begin{array}{c}\text { Sternotomy } \\
\text { (Steady state CPB) }\end{array}$ & Recovery \\
\hline $\begin{array}{l}\text { Dalrymple-Hay [15] (Ravitch- } \\
\text { type) }\end{array}$ & (19) & $\begin{array}{l}\text { Bi-ventricular perforation due to metal bar migration } \\
\qquad(6 \text { months })\end{array}$ & Sternotomy (CPB) & Recovery \\
\hline $\begin{array}{c}\text { Onursal [18] } \\
\text { (Ravitch-type) }\end{array}$ & (18) & $\begin{array}{l}\text { Migration of broken metal bar into the right ventricle } \\
\text { (4 years) }\end{array}$ & $\begin{array}{l}\text { Clamshell incision } \\
\text { (Steady state CPB) }\end{array}$ & Recovery \\
\hline $\begin{array}{l}\text { Aydemir [16] } \\
\text { (Ravitch-type) }\end{array}$ & (23) & $\begin{array}{l}\text { Rupture of the aortic sinus of Valsalva + Aorta-to-right ventricular } \\
\text { fistula, due to metal bar migration (1 month) }\end{array}$ & Sternotomy (CPB) & Recovery \\
\hline $\begin{array}{c}\text { Zhang [19] } \\
\text { (Ravitch-type) }\end{array}$ & $(53)$ & $\begin{array}{c}\text { Migration of } 2 \text { metal bars into the right ventricle, and pulmonary } \\
\text { trunk }+ \text { left main bronchus ( } 37 \text { years) }\end{array}$ & $\begin{array}{c}\text { Left anterior } \\
\text { thoracotomy }(\mathrm{CPB})\end{array}$ & Recovery \\
\hline $\begin{array}{l}\text { Biliboni [20] } \\
\text { (Ravitch-type) }\end{array}$ & $(25)$ & $\begin{array}{l}\text { Metal bar migration into the right ventricle and through the tricuspid } \\
\text { valve ( } 8 \text { years) }\end{array}$ & Sternotomy (CPB) & $\begin{array}{l}\text { Mild tricuspid } \\
\text { regurgitation }\end{array}$ \\
\hline \multicolumn{5}{|c|}{ Migration of broken sternal wire } \\
\hline $\begin{array}{l}\text { Barakat [21] } \\
\text { (Ravitch-type) }\end{array}$ & $(24)$ & $\begin{array}{l}\text { Pericardial tamponade due to broken sternal wire with pericardial/ } \\
\text { epicardial injury ( } 2 \text { years })\end{array}$ & Sternotomy & Recovery \\
\hline $\begin{array}{c}\text { Cope [22] } \\
\text { (Ravitch-type) }\end{array}$ & (24) & $\begin{array}{l}\text { Pericardial tamponade due to broken sternal wire with pericardial } \\
\text { injury ( } 2 \text { years })\end{array}$ & Thoracotomy & Recovery \\
\hline $\begin{array}{c}\text { Lee [23] } \\
\text { (Hybrid procedure) }\end{array}$ & $(15)$ & $\begin{array}{l}\text { Pericardial tamponade due to broken sternal wire with pericardial } \\
\text { injury (1 year) }\end{array}$ & NM & Recovery \\
\hline $\begin{array}{l}\text { Mieno }[24] \\
\text { (Sternal turnover) }\end{array}$ & (34) & $\begin{array}{l}\text { Migration of broken sternal wire into the ascending aorta } \\
\text { (28 years) }\end{array}$ & $\begin{array}{l}\text { Sternotomy, Prosthetic } \\
\text { replacement of the ascending } \\
\text { aorta }(\mathrm{CPB})\end{array}$ & Recovery \\
\hline
\end{tabular}

LCAE: Life-Threatening Cardiovascular Adverse Event; NM: Not Mentioned; CPB: Cardiopulmonary ByPass 
patients sustained intracardiac bar migration from two to 37 years after the initial procedure as a consequence of failure to remove the bar in a timely manner and/or broken material [17-20]. Injured cardiac structures are detailed in Table 1. Among these six patients, four underwent cardiac surgery under $\mathrm{CPB}$ and steady-state $\mathrm{CPB}$ in two cases. All these patients showed satisfactory results.

\section{Migration of broken sternal wire $(n=4)$}

In three patients, intrapericardial migration of a broken sternal steel wire $(n=2)$, or steel wire used for fixation of the retrosternal metallic bar in the midline during a hybrid technique (Ravitch + Nuss-bar), induced a hemopericardium and consecutive tamponade. Healing was achieved by draining blood, and removing the broken wire [21-23].

Finally, 28 years after sternal turnover the aortic migration of a broken sternal wire generated lesions severe enough to require prosthetic replacement of the ascending aorta under CPB [24].

\section{Minimally invasive repair of pectus excavatum}

After MIRPE, we identified a total of 56 LCAEs that resulted in 11 deaths, and two cases of severe hypoxic brain injury as a consequence of procedural cardiac arrest.

\section{Procedural heart injury $(n=27)$}

A heart injury may occur when inserting the introducer or the Nuss-bar into the thoracic cavity, or when repositioning a dislocated bar. We identified 27 intraoperative cardiac perforations or lacerations [11,13,25-30,32-47]. Nine patients had a history of cardiac surgery. Three were treated for PEx recurrence, two after MIRPE $[28,43]$. and one after Ravitch-type repair [34], respectively.

The cardiac injury resulted in death of three young patients $[19,29,37]$, and severe hypoxic brain injury in one [34]. Characteristics of patients are summarized in Table 2. Some data are lacking in five cases. Among the 22 other patients, PEx treatment was definitely discontinued in five. Finally, one patient underwent a later Nuss-bar placement under CPB for safety reasons [14].

\section{Trans myocardial migration of the Nuss-bar $(n=1)$}

One year after MIRPE, a patient sustained a trans myocardial migration of the Nuss-bar, discovered by an intense cardiac murmur audible by the patient himself. Removal of the bar and repair of considerable cardiac damages required a 14-hour CPB procedure, with a good result at two years, except for the absence of PEx correction. This case was reported in a non-medical journal [48].

\section{Cardiac injury during later Nuss-bar removal $(n=3)$}

Bouchard and coworkers [34] reported a lethal heart injury during Nuss-bar removal due to fibrotic adhesions between the bar and the pericardium, as a consequence of postoperative pericardial effusion. The same mechanism in a patient with a history of cardiac surgery for transposition of large vessels and mild pulmonary valve stenosis (Mustard technique) resulted in a double ventricular injury and massive bleeding [49]. Finally, a tear of the right ventricle with massive hemorrhage was reported by Sakakibara and coworkers [50]. The ventricular lesion was repaired under CPB. Retrospective analysis of the sagittal sections of the CT scan performed prior to the Nuss-bar removal showed evidence of intra ventricular bar migration.

\section{Vena cava injury or occlusion $(n=6)$}

Three patients suffered a procedural injury of the superior $(n=1)$ or inferior vena cava $(n=2)$. No information was provided about the case of superior vena cava injury [51]. An inferior vena cava injury occurred during a redo-MIRPE, which was repaired by sternotomy [43]. Last, another case of procedural inferior vena cava transfixion occurred, leading to cardiac arrest and patients' death after a long coma [52].

Three cases of acute obstruction of the inferior vena cava were reported $[31,53,54]$. At the end of the procedure, patients exhibited hemodynamic instability, oliguria and abdominal distension. An exploratory laparotomy was performed in two patients $[31,53]$. The diagnosis of acute obstruction of the inferior vena cava (probably as the consequence of a plication secondary to a sudden change in chest wall and diaphragm geometry) was made by cavography, ultrasound or CT scan. Although one patient sustained a procedural cardiac arrest [54], removal of the Nuss-bar was life-saving. However, no subsequent PEx correction was performed in any patient.

\section{Ascending aortic lesions $(\mathbf{n}=3)$}

Two months after MIRPE, the dislocation of the Nuss-bar in the cranial direction induced an hemopericardium due to a tear of the ascending aorta. After emergent sternotomy, the pericardium was emptied of blood. After careful removal of the Nuss-bar, hemostasis of the ascending aorta was achieved with pledgetted sutures [55]. A similar cranial dislocation caused a false aneurysm of the ascending aorta, which ruptured when the Nuss-bar was removed. A prosthetic replacement of the ascending aorta under CBP and deep hypothermia circulatory arrest was successfully performed [56].

Finally, a forensic medical case of lethal aortic hemorrhage during Nuss-bar removal was reported in a legal publication [57].

\section{Stenosis of the pulmonary artery or right ventricular outflow tract $(\mathbf{n}=3)$}

Two cases of stenosis of the pulmonary artery trunk [58] or right ventricular outflow tract [59], compressed by the curved left sided extremity of the Nuss- bar occurred as a result of a right lateral shift of the Nuss-bar. Symptomatology with dyspnea and/or systolic murmur retroceded after Nuss-bar removal, but the former patient showed tricuspid valve insufficiency as sequel [58]. Finally, 11 years after MIRPE, a 23-year-old patient who experienced a syncopal episode was found to have a retrosternal fibrous callus that severely compressed the right ventricle outflow tract. Fibrous callus was resected by video assisted thoracic surgery [60].

\section{Delayed pericardial events $(n=5)$}

Moss and coworkers [27] reported a case of major sepsis: bilateral pleural empyema and purulent pericarditis requiring pericardiectomy in addition to the Nuss-bar removal.

In a series of 335 patients, Park and coworkers [28] reported a case of constrictive pericarditis, as a result of post-operative pericardial effusion, which required a pericardiectomy during Nuss-bar removal.

Finally, we identified three cases of late-onset pericardial tamponade. One patient was treated with pericardiocentesis under echocardiographic control [61]. Retrocession of the effusion was achieved after Nuss-bar removal in the second patient [62]. The third patient underwent pericardiocentesis, and then pericardial window for recurrence, associated with Nuss-bar removal [63]. 
Table 2. Characteristics and outcomes for 27 patients who sustained a procedural cardiac injury during MIRPE

\begin{tabular}{|c|c|c|c|c|c|}
\hline Authors & $\begin{array}{l}\text { Patient age }(y) \\
\text { Prior surgery }\end{array}$ & $\begin{array}{l}\text { Cardiac injury. } \\
\text { (PCA) }\end{array}$ & Approach. (CPB) & $\begin{array}{l}\text { PEx } \\
\text { repair }\end{array}$ & Outcomes \\
\hline $\begin{array}{l}\text { Nuss[11]*, Hebra }[26]^{*}, \\
\text { Moss }[27]^{*}\end{array}$ & (8) & Right atrium/ventricle & $\begin{array}{l}\text { Sternotomy } \\
\text { (CPB) }\end{array}$ & Ravitch & Recovery \\
\hline Willekes [25] & $(\mathrm{NM}) \ll$ Child ». & $\begin{array}{l}\text { Right atrium/ventricle, } \\
\text { tricuspid valve }\end{array}$ & $\begin{array}{l}\text { Sternotomy } \\
\text { (CPB) }\end{array}$ & Ravitch & Recovery \\
\hline Park [28] & $\begin{array}{c}(26) \\
\text { MIRPE, bar dislocation }\end{array}$ & $\begin{array}{l}\text { Right atrium/ventricle (during } \\
\text { Nuss-bar replacement) }\end{array}$ & Thoracotomy & Nuss-bar & NM \\
\hline Gips [29] & (17) & $\begin{array}{l}\text { Right and left atrium, } \\
\text { Right ventricle. (PCA) }\end{array}$ & $\begin{array}{l}\text { Thoracotomy } \\
\text { (CPB) }\end{array}$ & Ravitch & Dead on Day 1 \\
\hline Belcher [30] & (16) & Right atrium & Sternotomy & Nuss-bar & Recovery \\
\hline Castellani [32] & $(\mathrm{NM})$ « Child ». & Right atrium/ventricle & Thoracotomy & NM & Recovery \\
\hline $\begin{array}{l}\text { Kuenzler [33]**, Bouchard } \\
\text { (Case 3) [34]** }\end{array}$ & $\begin{array}{l}\text { (11). } \\
\text { Atrial septal defect closure }\end{array}$ & Right ventricle & $\begin{array}{l}\text { Sternotomy } \\
\text { (CPB) }\end{array}$ & none & Recovery \\
\hline Bouchard (Case 1) [34] & (14) & $\begin{array}{l}\text { Right atrium, ventricular } \\
\text { septum }\end{array}$ & Sternotomy & none & $\begin{array}{l}\text { Persistent ventricular septal } \\
\text { defect }\end{array}$ \\
\hline $\begin{array}{c}\text { Bouchard (Case 2) } \\
{[34]}\end{array}$ & $\begin{array}{c}(18) \\
\text { Ravitch-type repair }\end{array}$ & Right atrium/ventricle. (PCA) & Thoracotomy (CPB) & none & Severe hypoxic brain injury \\
\hline $\begin{array}{c}\text { Hernandez (Case 2) } \\
{[13]}\end{array}$ & $\begin{array}{c}(5) \\
\text { Diaphragm hernia repair }\end{array}$ & «Cardiac perforation» & NM & none & $\begin{array}{l}\text { Recovery. Nuss-bar under } \\
\text { CPB at } 11\end{array}$ \\
\hline Tedde [36] & $(\mathrm{NM})$ & «Cardiac perforation » & NM & NM & Recovery \\
\hline Becmeur [35] & (18) & Right atrium/ventricle & $\begin{array}{l}\text { Sternotomy } \\
\text { (CPB) }\end{array}$ & none & Recovery \\
\hline Schaarschmidt [37] & (16) & Right atrium/ventricle (PCA) & Sternotomy & none & Dead on Day 11 \\
\hline Umuroglu [38] & $(\mathrm{NM})$ & «Myocardic laceration» & NM & Nuss-bar & NM \\
\hline $\begin{array}{c}\text { Craner [39], Jaroszewski } \\
{[46] * *}\end{array}$ & $\begin{array}{c}(29) \\
\text { Mitral valve repair }\end{array}$ & Right atrium & $\begin{array}{l}\text { Sternotomy } \\
\text { (CPB) }\end{array}$ & Nuss-bar & Recovery \\
\hline Jeong [40] & (17) & Left ventricle laceration & Sternotomy & Nuss-bar & Recovey \\
\hline Zhang [41] & $\begin{array}{l}\text { (11) } \\
\text { Ventricular septal defect } \\
\text { closure }\end{array}$ & Right atrium (PCA) & $\mathrm{NM}$ & $\mathrm{NM}$ & Dead on Day 17 \\
\hline Pilegaard [43] & (NM). MIRPE, recurrence & Right ventricle laceration & Sternotomy & Nuss-bar & Recovery \\
\hline Ersen [42] & $(\mathrm{NM})$ «Adult » & «Small ventricle defect» & Thoracotomy & Nuss-bar & Recovery \\
\hline $\operatorname{Li}[45]$ & $\begin{array}{l}(\mathrm{NM}) \text { « Child» } \\
\text { « Cardiac surgery » }\end{array}$ & «Cardiac perforation » & $\mathrm{NM}$ & $\mathrm{NM}$ & NM \\
\hline $\begin{array}{c}\text { Jaroszewski (Park's case) } \\
{[46]}\end{array}$ & $\begin{array}{c}(36) \\
\text { Mitral valve replacement }\end{array}$ & Right atrium & $\begin{array}{l}\text { Sternotomy } \\
\text { (CPB) }\end{array}$ & Nuss-bar & Recovery \\
\hline $\begin{array}{c}\text { Jaroszewski (Obemeyer's } \\
\text { case) [46] }\end{array}$ & $\begin{array}{c}\quad(20) \\
\text { Transposition of great vessels }\end{array}$ & Right atrium & $\begin{array}{l}\text { Sternotomy } \\
\text { (CPB) }\end{array}$ & Nuss-bar & Recovery \\
\hline $\begin{array}{l}\text { Jaroszewski (Obemeyer's } \\
\text { case) }[46]\end{array}$ & $\begin{array}{c}\text { (NM) } \\
\text { Atrial/ventricular septal } \\
\text { defect closure }\end{array}$ & Right atrial appendage & Sternotomy & Nuss-bar & Recovery \\
\hline $\begin{array}{c}\text { Jaroszewski (Yüksel's case) } \\
\text { [46] }\end{array}$ & $\begin{array}{c}(22) \\
\text { Atrial septal defect closure }\end{array}$ & Right atrium & Thoracotomy. & Nuss-bar & Recovery \\
\hline Ghionzoli [44] & (14) & Right atrium & Thoracotomy & Nuss-bar & Recovery \\
\hline Chen [47] & $\begin{array}{c}(\mathrm{NM}) \\
\text { Atrial septal defect closure }\end{array}$ & Right atrium & Sternotomy & Nuss-bar & Recovery \\
\hline Chen [47] & $\begin{array}{l}\qquad(\mathrm{NM}) \\
\text { Atrial septal defect closure }\end{array}$ & Right atrium & Sternotomy & Nuss-bar & Recovery \\
\hline
\end{tabular}

*: threefold published case; **: twofold published case; NM: Not Mentioned; PCA: Procedural Cardiac Arrest; CPB: Cardiopulmonary By-Pass

\section{MIRPE and cardiac arrest}

Severe procedural complications, either during the initial operation or later Nuss-bar removal, were responsible for cardiac arrest in eight patients $[29,34,41,52,54,57]$. Three of them died early and three after a long coma; and one retained severe hypoxic brain injury [34]. Finally, only one patient fully recovered [54].

Redlinger and coworkers reported two intraoperative cardiac arrests in their series of 100 cases of re-intervention by MIRPE for PEx recurrence, in relation to right ventricular dysfunction in patients having undergone a previous Ravitch procedure and consecutive acquired thoracic dystrophy. Cardiac arrest occurred at the beginning of re-intervention by MIRPE, and Nuss-bar removal, respectively
[64]. Recently, a case of unintended intraoperative cardiac arrests was reported by Zou and coworkers: two attempts for intrathoracic placement of the Nuss-bar resulted in cardiac arrest, which reverted after Nuss-bar removal. The PEx cure was therefore abandoned [65].

Late-onset cardiac arrest, probably as a consequence of cardiac rhythm disorder, is a tragedy because the presence of the Nuss-bar prohibits effective cardiopulmonary resuscitation manoeuvers as demonstrated by three well-documented cases [66-68]. Finally, two additional lethal late-onset cardiac arrest in patients with the Nuss-bar in place were reported in literature, however without any information about the cardiopulmonary resuscitation manoeuvers that might have been implemented $[2,69]$. 
In total, among the eight patients who sustained a procedural or late-onset cardiac arrest without any surgical complications, five died and one suffered hypoxic brain injury [64].

\section{Comment}

The present study is an overview of severe adverse events involving the heart and/or large mediastinal vessels occurring during PEx surgery or later. In the field of open repair, we identified 13 LCAEs resulting in one death, and 56 related to MIRPE resulting in 11 deaths, and two cases of severe hypoxic brain injury as a consequence of intraoperative cardiac arrest.

In open surgery, the use of Kirchner wire for fixation of the remodeled anterior chest wall is currently abandoned, and the reported postoperative cardiac perforation [14] should no longer be observed. Other LCAEs were the result of technical errors and/or a failure to follow up patients over the mid/long term, thus impeding to remove the metallic material in a timely manner. Therefore, it has been shown that intrapericardial or intracardiac migration of metallic materials used in PEx open repair was related to the time these materials were left in place, or as a consequence of delayed material rupture [19]. Intracardiac migrations of the sternal support bar should be avoided by using material of sufficient length, thus avoiding unintended dislocation into the mediastinum; and rigid enough to avoid torsion or rupture [8]. Another basic precaution is removing the bar at six months after PEx repair. Finally, the use of steel wire for sternal osteotomy fixation should be avoided because of the risk of rupture and subsequent intrapericardial or even aortic migration of the broken material [24].

The LCAEs related to MIRPE which we identified are much more worrying by their nature and number. In this regard, in Kenzler and Stolar's general review of PEx surgical management it is significant that the paragraph on surgical complications deals primarily with MIRPE [33]. A recent article by Hebra and coworkers [70] is expected to be an overview of miscellaneous severe adverse events and mortality related to MIRPE. Surprisingly, they identified few LCAEs in the literature: 19 cases, including 12 cardiac perforations and four cases of mortality. Furthermore, in their article, the crucial problem of cardiac arrest during MIRPE or later was not mentioned. Despite the fact that Hebra and coworkers pooled the miscellaneous severe adverse events that they identified with unpublished cases from a survey of members of the Chest Wall International Group, the morbidity and mortality of MIRPE remained severely underestimated, which we stressed in a correspondence [71]. In fact, by pooling the results of our present study (56 LCAEs) with the 20 unpublished LCAEs of the Chest Wall International Group' survey reported by Hebra and coworkers [70] the number of LCAEs related to MIRPE rises to 76, including 45 cardiac injuries, 18 cases of mortality and two cases of severe hypoxic brain injury. Notably, it has been shown that a history of median sternotomy for cardiac surgery was a significant risk factor for the occurrence of cardiac injury with a reported rate from 4 to $7 \%[46,47]$. Thus, we feel that MIRPE might be discouraged in the setting of PEx repair in this patient population [72].

We are convinced that the technique refinements developed over the years to avoid cardiac injuries, well described in detail by Becmeur and coworkers [35], and then by Hebra and coworkers [70], have undoubtedly helped to reduce the number of LCAEs related to MIRPE. However, some of them are unpredictable, such as acute obstructions of the inferior vena cava, procedural cardiac arrests, or delayed cataclysmic hemorrhages especially during later Nuss-bar removal.
Last, the impossibility of implementing effective cardiac resuscitation manoeuvers due to the presence of the Nuss-bar in the event of lateonset cardiac arrest deserves to be stressed [67].

Finally, whatever the PEx repair performed, the occurrence of a LCAE frequently mandates a cardiac/aortic procedure under CPB. After open repair, there were scheduled procedures in the majority of cases (6/7). In contrast, after MIRPE, these CPB procedures were mainly performed in an emergency setting (10/12). Thus, for safety reason, MIRPE should be carried out in an operating room where a bypass team can be brought in if necessary [34].

We are well aware of the imperfect nature of our study, since the number of patients, operated by open repair or MIRPE, respectively, is unknown. Thus, it seems questionable to extrapolate from a rate of severe or lethal complications after MIRPE as Hebra and coworkers did in their study [70]. However, given their actual number, their severity and the unintended nature of such complications, we did not include MIRPE in our therapeutic armamentarium for the treatment of PEx. When the operation is considered we remain faithful to the use of a simplified Ravitch-type repair [7], which has been demonstrated as safe and reliable, notably in patients with a past history of cardiac surgery $[72,73]$.

\section{Acknowledgments}

We thank Professor Eric Kipnis for editorial assistance, and friendship.

\section{References}

1. Benhamed L, Hysi I, Wurtz AJ (2013) eComment. Is overgrowth of costal cartilages the unique cause of pectus deformities? Interact Cardiovasc Thorac Surg 17: 763. [Crossref]

2. Kelly RE, Goretsky MJ, Obermeyer R, Kuhn MA, Redlinger R, et al. (2010) Twentyone years of experience with minimally invasive repair of pectus excavatum by the Nuss procedure in 1215 patients. Ann Surg 252: 1072-1081. [Crossref]

3. Lam MW, Klassen AF, Montgomery CJ, LeBlanc JG, Skarsgard ED (2008) Qualityof-life outcomes after surgical correction of pectus excavatum: a comparison of the Ravitch and Nuss procedures. J Pediatr Surg 43: 819-825. [Crossref]

4. Neviere R, Montaigne D, Benhamed L, Catto M, Edme JL, et al. (2011) Cardiopulmonary response following surgical repair of pectus excavatum in adult patients. Eur J Cardiothorac Surg 40: e77-e82. [Crossref]

5. Shamberger RC, Welch KJ (1988) Surgical repair of pectus excavatum. J Pediatr Surg 23: 615-622. [Crossref]

6. Fonkalsrud EW, Dunn JC, Atkinson JB (2000) Repair of pectus excavatum deformities 30 years of experience with 375 patients. Ann Surg 231: 443-448. [Crossref]

7. Wurtz A, Rousse N, Benhamed L, Conti M, Hysi I, et al. (2012) Simplified open repair for anterior chest wall deformities. Analysis of results in 205 patients. Orthop Traumatol Surg Res 98: 319-326. [Crossref]

8. Brian E, Benhamed L, Wurtz A (2016) Substernal Titanium Support After Pectus Open Repair. Ann Thorac Surg 101: 832-833. [Crossref]

9. Saxena AK, Willital GH (2007) Valuable lessons from two decades of pectus repair with the Willital-Hegemann procedure. J Thorac Cardiovasc Surg 134: 871-876. [Crossref]

10. Tóth T, Szöts I, Forgon J, Záborsky A (1986) [Surgical treatment of pectus excavatum by "turn over" of the sternum]. Zentralbl Chir 111: 1515-1518. [Crossref]

11. Nuss D, Kelly RE, Croituru DP, Swoveland B (1998) Repair of pectus excavatum. Pediatric Endosurgery \& Innovative Techniques 2: 205-221.

12. Moher D, Liberati A, Tetzlaff J, Altman DG, Group P (2009) Preferred reporting items for systematic reviews and meta-analyses: the PRISMA statement. PLoS Med 6: e1000097. [Crossref]

13. Hernández S, Fernández A, Ramírez M, López S, De la Torre CA, et al. (2011) [Correction of the complicated pectus excavatum with extracorporeal circulation (ECC) support]. Cir Pediatr 24: 44-47. [Crossref] 
14. Pircova A, Sekarski-Hunkeler N, Jeanrenaud X, Ruchat P, Sadeghi H, et al. (1995) Cardiac perforation after surgical repair of pectus excavatum. J Pediatr Surg 30: 15061508. [Crossref]

15. Dalrymple-Hay MJ, Calver A, Lea RE, Monro JL (1997) Migration of pectus excavatum correction bar into the left ventricle. Eur J Cardiothorac Surg 12: 507509. [Crossref]

16. Aydemir B, Sokullu O, Hastaoglu O, Bilgen F, Celik M, et al. (2011) Aorta-to-right ventricular fistula due to pectus bar migration. Thorac Cardiovasc Surg 59: 51-52. [Crossref]

17. Elami A, Lieberman Y (1991) Hemopericardium: a late complication after repair of pectus excavatum. J Cardiovasc Surg (Torino) 32: 539-540. [Crossref]

18. Onursal E, Toker A, Bostanci K, Alpagut U, Tireli E (1999) A complication of pectus excavatum operation: endomyocardial steel strut. Ann Thorac Surg 68: 1082-1083. [Crossref]

19. Zhang R, Hagl C, Bobylev D, Breymann T, Schmitto JD, et al. (2011) Intrapericardia migration of dislodged sternal struts as late complication of open pectus excavatum repairs. J Cardiothorac Surg 6: 40.

20. Biliboni Lage I, Khan K, Kaabneh A, Kendall S (2013) Late coronary artery and tricuspid valve injury post pectus excavatum surgery. Interact Cardiovasc Thorac Surg 17: 748-750. [Crossref]

21. Barakat MJ, Morgan JA (2004) Haemopericardium causing cardiac tamponade: a late complication of pectus excavatum repair. Heart 90: e22. [Crossref]

22. Cope SA, Rodda J (2004) Cardiac tamponade presenting to the emergency department after sternal wire disruption. Emerg Med J 21: 389-390. [Crossref]

23. Lee SH, Cho BS, Kim SJ, Lee SY, Kang MH, et al. (2013) Cardiac Tamponade caused by broken sternal wire after pectus excavatum repair: a case report. Ann Thorac Cardiovasc Surg 19: 52-54. [Crossref]

24. Mieno S, Ozawa H, Katsumata T (2010) Ascending aortic injury caused by a fractured sternal wire 28 years after surgical intervention of pectus excavatum. $J$ Thorac Cardiovasc Surg 140: e18-20. [Crossref]

25. Willekes CL, Backer CL, Mavroudis C (1999) A 26-year review of pectus deformity repairs, including simultaneous intracardiac repair. Ann Thorac Surg 67: 511-518. [Crossref]

26. Hebra A, Swoveland B, Egbert M, Tagge EP, Georgeson K, et al. (2000) Outcome analysis of minimally invasive repair of pectus excavatum: review of 251 cases. $J$ Pediatr Surg 35: 252-257. [Crossref]

27. Moss RL, Albanese CT, Reynolds M (2001) Major complications after minimally invasive repair of pectus excavatum: case reports. J Pediatr Surg 36: 155-158. [Crossref]

28. Park HJ, Lee SY, Lee CS (2004) Complications associated with the Nuss procedure: analysis of risk factors and suggested measures for prevention of complications. $J$ Pediatr Surg 39: 391-395. [Crossref]

29. Gips H, Zaitsev K, Hiss J (2008) Cardiac perforation by a pectus bar after surgical correction of pectus excavatum: case report and review of the literature. Pediatr Surg Int 24: 617-620. [Crossref]

30. Belcher E, Arora S, Samancilar O, Goldstraw P (2008) Reducing cardiac injury during minimally invasive repair of pectus excavatum. Eur J Cardiothorac Surg 33: 931-933. [Crossref]

31. Nath DS, Wells WJ, Reemtsen BL (2008) Mechanical occlusion of the inferior vena cava: an unusual complication after repair of pectus excavatum using the nuss procedure. Ann Thorac Surg 85: 1796-1798. [Crossref]

32. Castellani C, Schalamon J, Saxena AK, Hoellwarth ME (2008) Early complications of the Nuss procedure for pectus excavatum: a prospective study. Pediatr Surg Int 24: 659-666. [Crossref]

33. Kuenzler KA, Stolar CJ (2009) Surgical correction of pectus excavatum. Paediatr Respir Rev 10: 7-11. [Crossref]

34. Bouchard S, Hong AR, Gilchrist BF, Kuenzler KA (2009) Catastrophic cardiac injuries encountered during the minimally invasive repair of pectus excavatum. Sem Pediatr Surg 18: 66-72. [Crossref]

35. Becmeur F, Gomes Ferreira C, Haecker FM, Schneider A, Lacreuse I (2011) Pectus excavatum repair according to Nuss: is it safe to place a retrosternal bar by a transpleural approach, under thoracoscopic vision? J Laparoendosc Adv Surg Tech 21: 757-761. [Crossref]
36. Tedde ML, Campos JR, Das-Neves-Pereira JC, Abrao FC, Jatene FB (2011) The search for stability: bar displacement in three series of pectus excavatum patients treated with the Nuss technique. Clinics (Sao Paulo) 66: 1743-1746. [Crossref]

37. Schaarschmidt K, Lempe M, Schlesinger F, Jaeschke U, Park W, et al. (2013) Lesson learned from lethal cardiac injury by nuss repair of pectus excavatum in a 16-year-old Ann Thorac Surg 95: 1793-1795. [Crossref]

38. Umuroglu T, Bostanca K, Thomas DT, Yuksel M, Gogus FY (2013) Perioperative anesthetic and surgical complications of the Nuss procedure. J Cardiothorac Vasc Anesth 27: 436-440. [Crossref]

39. Craner R, Weis R, Ramakrishna H (2013) Emergent cardiopulmonary bypass during pectus excavatum repair. Ann Card Anaesth 16: 205-208. [Crossref]

40. Jeong JY, Suh JH, Yoon JS, Park CB1 (2014) Delayed-onset hypovolemic shock after the Nuss procedure for pectus excavatum. J Cardiothorac Surg 9: 15. [Crossref]

41. Zhang DK, Tang JM, Ben XS, Xie L, Zhou HY, et al. (2015) Surgical correction of 639 pectus excavatum cases via the Nuss procedure. $J$ Thorac Dis 7: 1595-1605. [Crossref]

42. Ersen E, Demirkaya A, Kilic B, Kara HV, Yakşi O, et al. (2016) Minimally invasive repair of pectus excavatum (MIRPE) in adults: is it a proper choice? Videosurgery Miniinv 11: 98-104. [Crossref]

43. Pilegaard HK (2016) Single centre experience on short bar technique for pectus excavatum. Ann Cardiothorac Surg 5: 450-455. [Crossref]

44. Ghionzoli M, Deaconu DE, Ugolini S, Lo Piccolo R, Messineo A (2017) Lef anterolateral emergency thoracotomy during the Nuss procedure: Lifesaving shortcut. Pediatr Int 59: 103-114. [Crossref]

45. Li S, Yang D, Ma Y, Tang ST, Yang L, et al. (2017) Hybrid Nuss Procedure for Pectus Excavatum With Severe Retrosternal Adhesions After Sternotomy. Ann Thorac Surg 103: 1573-1577. [Crossref]

46. Jaroszewski DE, Gustin PJ, Haecker F-M, Pilegaard H, Park HJ, et al. (2017) Pectu excavatum repair after sternotomy: the Chest Wall International Group experience with substernal Nuss bars. Eur J Cardiothorac Surg 52: 710-717. [Crossref]

47. Chen C, Li X, Zhang N, Yu J, Yan D, et al. (2018) Different Nuss procedures and risk management for pectus excavatum after surgery for congenital heart disease. J Pediatr Surg 53: 1964-1969. [Crossref]

48. Web based. (n.d.). http://www.dailymail.co.uk/health/article-2739727/Bulliedteenager-nearly-died-steel-bar-inserted-disguise-sunken-chest-came- $1 \mathrm{~cm}$-heart.html (2016).

49. Haecker FM, Berberich T, Mayr J, Gambazzi F (2009) Near-fatal bleeding after transmyocardial ventricle lesion during removal of the pectus bar after the Nuss procedure. J Thorac Cardiovasc Surg 138: 1240-1241. [Crossref]

50. Sakakibara K, Kinoshita H, Ando K, Yasuda Y, Mori Y, et al. (2013) Right ventricular perforation due to a stabilizing bar installed for the Nuss procedure. Minerva Anestesiol 79: 820-821. [Crossref]

51. Tikka T, Kalkat MS, Bishaya E, Steyn RS, Rajesh PB, et al. (2016) A 20-year review of pectus surgery: an analysis of factors predictive of recurrence and outcomes. Interact CardioVasc Thorac Surg 23: 908-913. [Crossref]

52. Merlini T, Lhommet P, Dupont P, Dumont $\mathrm{P}$ (2018) La chirurgie du pectus excavatum expérience du CHU de Tours. Journal de chirurgie thoracique et cardiovasculaire 22.

53. Harris B, Bushman GA, Hastings LA (2009) Inferior vena cava obstruction after pectus excavatum repair. J Cardiothorac Vasc Anesth 23: 515-517. [Crossref]

54. Ballouhey Q, Léobon B, Trinchéro JF, Baunin C, Galinier P, et al. (2012) Mechanical occlusion of the inferior vena cava: an early complication after repair of pectus excavatum using the Nuss procedure. J Pediatr Surg 47: e1-e3. [Crossref]

55. Hoel TN, Rein KA, Svennevig JL (2006) A life-threatening complication of the Nuss procedure for pectus excavatum. Ann Thorac Surg 81: 370-372. [Crossref]

56. Jemielity M, Pawlak K, Piwkowski C, Dyszkiewicz W (2011) Life-threatening aortic hemorrhage during pectus bar removal. Ann Thorac Surg 91: 593-595. [Crossref]

57. Massachusetts Lawyers Weekly, May 14, 2015.

58. Mazur L, de Ybarrondo L, Pickard L, Rao PS (2012) Development of supravalvular pulmonary artery stenosis following a Nuss procedure. J Pediatr Surg 47: e61-64. [Crossref]

59. Maagaard M, Udholm S, Hjortdal VE, Pilegaard HK (2015) Right ventricular outflow tract obstruction caused by a displaced pectus bar 30 months following the Nuss procedure. Eur J Cardiothorac Surg 47: e42-43. [Crossref] 
60. Obert L, Munyon R, Choe A, Rubenstein J, Azizkhan R (2012) Rare late complication of the Nuss procedure: a case report. J Pediatr Surg 47: 593-597. [Crossref]

61. Yan MH, Cheng YL, Tsai CS, Li CY (2008) Delayed cardiac tamponade after the Nuss procedure for pectus excavatum: a case report and simple management. Heart Surg Forum 11: E129-131. [Crossref]

62. Yano M, Fukuda Y, Miura S, Saku K (2013) Epicarditis with late postoperative period pectus excavatum. Intern Med 52: 637-638. [Crossref]

63. Baek JH, Lee YU, Jung TE, Lee DH, Lee JC (2017) Late cardiac tamponade following Nuss procedure for pectus excavatum. $J$ Thorac Dis 9: E424-424E426. [Crossref]

64. Redlinger RE Jr, Kelly RE Jr, Nuss D, Kuhn MA, Obermeyer RJ, et al. (2011) One hundred patients with recurrent pectus excavatum repaired via the minimally invasive Nuss technique-effective in most regardless of initial operative approach. $J$ Pediatr Surg 46: 1177-1181. [Crossref]

65. Zou J, Luo C, Liu Z, Cheng C (2017) Cardiac arrest without physical cardiac injuryduring Nuss repair of pectus excavatum. J Cardiothorac Surg 12: 61. [Crossref]

66. Zallen GS, Glick PL (2004) Miniature access pectus excavatum repair: Lessons we have learned. J Pediatr Surg 39: 685-689. [Crossref]
67. Zoeller GK, Zallen GS, Glick PL (2005) Cardiopulmonary resuscitation in patients with a Nuss bar--a case report and review of the literature. J Pediatr Surg 40: 17881791. [Crossref]

68. Nakahara O, Ohshima S, Baba H (2015) Cardiopulmonary arrest during the Nuss procedure: case report and review. Acute Med Surg 2: 250-252. [Crossref]

69. Sacco Casamassima MG, Wong LL, Papandria D, Abdullah F, Vricella LA, et al. (2013) Modified nuss procedure in concurrent repair of pectus excavatum and open heart surgery. Ann Thorac Surg 95: 1043-1049. [Crossref]

70. Hebra A, Kelly RE, Ferro MM, Yuksel M, Campos JRM, et al. (2018) Life-threatening complications and mortality of minimally invasive pectus surgery. J Pediatr Surg 53: 728-732.

71. De Wolf J, Brian E, Wurtz A (2018) Letter to the Editor. J Pediatr Surg 53: 857-858. [Crossref]

72. Brian E, Wurtz A (2017) The Nuss Procedure After Prior Cardiac Surgery: Friend or Foe? Ann Thorac Surg 104: 1759. [Crossref]

73. Hysi I, Vincentelli A, Juthier F, Benhamed L, Banfi C, et al. (2015) Cardiac surgery and repair of pectus deformities: When and how? Int J Cardiol 194: 83-86. [Crossref]

Copyright: (92019 De Wolf J. This is an open-access article distributed under the terms of the Creative Commons Attribution License, which permits unrestricted use, distribution, and reproduction in any medium, provided the original author and source are credited. 